\title{
Botany
}

\section{Factors influencing the morphogenesis of galls induced by Calophya mammifex (Calophyidae) on Schinus polygama (Anacardiaceae) leaves}

\begin{tabular}{|c|c|}
\hline Journal: & Botany \\
\hline Manuscript ID & cjb-2018-0078.R1 \\
\hline Manuscript Type: & Article \\
\hline Date Submitted by the Author: & 26-May-2018 \\
\hline Complete List of Authors: & $\begin{array}{l}\text { Guedes, Lubia; Universidad de Concepcion, Departamento de Botánica. } \\
\text { Facultad de Ciencia Naturales y Oceanográficas } \\
\text { Aguilera, Narciso; Universidad de Concepcion, Departamento de } \\
\text { Silvicultura. Facultad de Ciencias Forestales. } \\
\text { Ferreira, Bruno; Universidade Federal de Minas Gerais, Botânica } \\
\text { Becerra, José; Universidad de Concepcion, Departamento de Botánica. } \\
\text { Facultad de Ciencias Naturales y Oceanográficas } \\
\text { Sáez, Katia; Universidad de Concepcion, Departamento de Estadística. } \\
\text { Facultad de Ciencias Físicas y Matemática } \\
\text { Péres, Claudia; Universidad de Concepcion, Botánica } \\
\text { Hernández, Victor; Universidad de Concepcion, Departamento de Botánica. } \\
\text { Facultad de Ciencias Naturales y Oceanográficas } \\
\text { Isaias, Rosy; Universidade Federal de Minas Gerais, Botânica }\end{array}$ \\
\hline Keyword: & $\begin{array}{l}\text { Calophyids, gall, histochemical, morphogenetical potentialities, } \\
\text { Mediterranean climatic }\end{array}$ \\
\hline $\begin{array}{r}\text { Is the invited manuscript for } \\
\text { consideration in a Special } \\
\text { Issue? : }\end{array}$ & Not applicable (regular submission) \\
\hline
\end{tabular}




\section{Factors influencing the morphogenesis of galls induced by Calophya mammifex}

\section{(Calophyidae) on Schinus polygama (Anacardiaceae) leaves}

Lubia M Guedes ${ }^{1}$, Narciso Aguilera ${ }^{2}$, Bruno G Ferreira ${ }^{3}$, José Becerra ${ }^{1}$, Katia Saéz ${ }^{4}$, Claudia Pérez ${ }^{1}$, Victor Hernández $z^{1}$ and Rosy MS Isaias ${ }^{3}$

${ }^{1}$ Department of Botany, Facultad de Ciencias Naturales y Oceanográficas, Universidad de Concepción, Casilla 160-C, CP 4030000, Concepción, Chile

${ }^{2}$ Department of Forestry, Facultad de Ciencias Forestales, Universidad de Concepción, Casilla 160-C, CP 4030000, Concepción, Chile

${ }^{3}$ Department of Botany, Instituto de Ciências Biológicas, Universidade Federal de Minas Gerais, Av. Antônio Carlos, 6627, 31270-090, Pampulha, Belo Horizonte, Minas Gerais, Brazil

${ }^{4}$ Department of Statistics, Facultad de Ciencias Físicas y Matemáticas, Universidad de Concepción, Casilla 160-C, Concepción, Chile

*Corresponding author: Rosy M. S. Isaias. E-mail: rosy@icb.ufmg.br. Tel: +553134092687. Fax: +553134092671 . 


\begin{abstract}
Environment, plant and gall-inducing insect genotypes are key factors in determining the morphogenesis of galls. However, the exact roles of these factors have not been clarified. We used anatomical and histochemical methods to evaluate determinant factors in the final structure of galls induced by Calophya mammifex on Schinus polygama leaves, under the Mediterranean climatic conditions of southern Chile. Also, we compared mature galls with those induced by the congeneric C. rubra on the same host plant. Calophya mammifex develops a univoltine life cycle and a diapause period in the Mediterranean climatic conditions of southern Chile. Morphogenetic and histochemical leaf patterns were altered by C. mammifex feeding activity. For the first time, two specialized tissue compartments, a nutritive-like tissue and a common storage tissue, are reported for Calophyidae-induced galls in the Mediterranean region of southern Chile. Galls induced by $C$. mammifex and C. rubra have sufficient anatomical and histochemical alterations to be diagnosed as complex structures, whose distinction in vascular system differentiation implies structural constraints imposed by host plant organs.
\end{abstract}

Keywords: calophyids; gall; histochemistry; morphogenetic potentialities; Mediterranean climate; univoltinism 


\section{Introduction}

Gall inducers are biotic factors capable of altering the morphogenetic fate of host plant cells, generating specific gall phenotypes for each host plant (Isaias and Oliveira 2014). Schinus polygama (Cav.) (Cabrera) (Anacardiaceae) responds differently to four different gall-inducing insects - two Hemiptera (Calophyidae) and two Lepidoptera (Guedes et al. 2018). Calophya mammifex (Burckhardt \& Basset) (Calophyidae) induces globoid leaf galls, the most common morphotype, whereas Calophya rubra (Blanchard) (Calophyidae) induces conical stem galls on S. polygama (Burckhardt and Basset 2000; Guedes et al. 2018). Insects with similar feeding habits, such as the calophyids, are expected to influence host plant tissues similarly (Rohfritsch 1992). Moreover, plant responses to gall inducer feeding habits should also be considered, for they are specific and specialized (Meyer 1987). Galls are host plant cell build-ups, and their development must be constrained by host plant organ and cell morphogenetic potentialities (Isaias and Oliveira 2014), to consequently determine whether galls may develop complex or simple structures (Formiga et al. 2015).

Histological, histochemical, and histometric alterations, as well as the differentiation of specialized storage cells and tissues, imply distinct levels of structural complexity among galls (Ferreira et al. 2017a). Galls with little organization and tissue differentiation, several layers of parenchymatic cells, and no metabolic storage tissues are considered simple galls (Rohfritsch and Anthony 1992; Isaias et al. 2014; Ferreira et al. 2017a). Gall complexity may be attributed to the vascular bundle development, and primary metabolite storage (Ferreira et al. 2017a), features that confer an intermediate level of structural complexity to Calophyidae-induced galls ( $C$. cf. duvauae and C. rubra) (Dias et al. 2013a; Guedes et al. 2018). 
Although dense trichomes, large nymphal chambers, and tissue hyperplasia have been described in C. mammifex mature globoid leaf galls on $S$. polygama (Guedes et al. 2016), their anatomical development remains unknown. Phenological, anatomical and histochemical peculiarities of the S. polygama - C. rubra system associated with Mediterranean climatic conditions of southern Chile have been recently studied (Guedes et al. 2018), and could be extended to the $S$. polygama - C. mammifex system, as evaluated in this study. Therefore, the current study model is non-galled $S$. polygama leaves, as control-organs, and galls induced by $C$. rubra (Guedes et al. 2018), a congeneric species of C. mammifex, for comparative analysis of structural alterations.

Although synergistic interactions between environment, host-plant and inducer genotypes can determine specific gall phenotype (Weis et al. 1988; Abrahamson and Weiss 1997), their roles in determining gall morphology is not clearly understood (Moura et al. 2008). The $S$. polygama superhost and C. mammifex/C. rubra-induced galls constitute an appropriate model to study the role of host organ constraints on gall development and on the extended phenotypes of galling herbivores. The following questions are addressed: (i) What are the diagnostic features of C. mammifex leaf galls on S. polygama? (ii) Should galls induced by C. mammifex and C. rubra have similarities? And (iii) Are there morphogenetic constraints in host leaves expressed on $C$. mammifex-induced galls?

\section{Materials and methods}

\section{Sampling and collection site}

A S. polygama population located in the Mediterranean climate of southern Chile, in Bío-bío Region, Nuble Province, at kilometre 4 on the Itata highway $\left(36^{\circ} 39^{\prime} 32^{\prime \prime S}, 72^{\circ} 16^{\prime} 43^{\prime \prime} \mathrm{W}\right.$ at 150 m.a.s.l) was studied. The Mediterranean climate of southern Chile has cold, wet winters (June - 
August) and hot, dry summers (December - February) (Giorgi and Lionello 2008); particularly, the climatic regime of central Chile is characterized by absence of summer rainfall and associated thunderstorm activity (Armesto et al. 2007). Meteorological data were obtained from Weatherbase (http://www.weatherbase.com). During the study period, July 2015 and March 2016, the highest temperatures were recorded in January $2016\left(36^{\circ} \mathrm{C}\right)$, and the lowest in June, July and August $2015\left(-3{ }^{\circ} \mathrm{C},-1{ }^{\circ} \mathrm{C}\right.$ and $-3{ }^{\circ} \mathrm{C}$, respectively). The month with the highest average precipitation was June $(185.4 \mathrm{~mm})$, and the month with the lowest average precipitation was February $(2.5 \mathrm{~mm})$.

For vegetative phenology, we randomly marked ten S. polygama individuals and observed monthly. Leaf sprouting, senescent leaves and leaf fall were evaluated visually. We collected branches with and without galls from each tree monthly, which were stored in plastic bags and transferred to the Laboratory of Natural Product Chemistry at the Universidad de Concepción. On each branch, we assessed twenty leaves $(n=20)$ with galls by direct observation, and registered gall position as follows: apex, mid-portion, basal regions, leaf margin, and leaf lamina.

We randomly marked five trees for anatomical and cyto-histometric analysis, and collected five $(n=5)$ non-galled mature leaves (NGL) and globoid leaf galls (GLG) from each tree at growth and development (GD), maturation (MP), and senescence (SP) stages ( $n=5$ per developmental stage). Leaf galls were sorted according to insect instar (Guedes et al. 2018), as follows: GD - first to fourth instar; MP - fifth instar; and SP - open gall and absent gall-inducer. In addition, conical stem galls (CSG) in maturation phase $(n=5)$ were collected for comparison with GLG. Also, some GLG were dissected with a razor blade under the stereomicroscope and grouped according to insect instar. Nymphs were collected and preserved in $70 \%$ ethanol, then sent to Daniel Burckhardt at the Natural History Museum of Switzerland (NHMB) for species 
identification. Several voucher specimens were deposited in NHMB under accession numbers NMB-PSYLL0004288 - NMB-PSYLL0004293.

Anatomical and cyto-histometric analysis

Following each collection, the NGL, GLG and CSG samples $(n=5)$ were fixed in $4 \%$ Karnovsky (2.5\% glutaraldehyde and $4.5 \%$ formaldehyde in phosphate buffer $0.1 \mathrm{M}$, modified to $\mathrm{pH} 7.2$; O’Brien and McCully 1981), $2.5 \%$ glutaraldehyde (Karnovsky 1965), or FAA (37\% formaldehyde, glacial acetic acid, and $50 \%$ ethanol, 1:1:18 v/v/v), and subsequently stored in 70 $\%$ ethanol. Fixed samples were dehydrated in n-butyl series (Johansen 1940), embedded in Paraplast $^{\circledR}$ (Kraus and Arduin 1997), sectioned (12-18 $\left.\mu \mathrm{m}\right)$ with a rotary microtome (Leica 2035 Biocut), stained with $0.5 \%$ astra blue and safranin (9:1 v/v) (Bukatsch 1972) and mounted with clear varnish (Paiva et al. 2006). The histological slides were observed and photographed using a light microscope (Leica ${ }^{\circledR}$ DM500) coupled with a digital camera (Leica ${ }^{\circledR}$ ICC50 HD).

Histometric and cytometric data were obtained from NGL, GLG and CSG photomicrographs, using AxioVision LE software (CarlZeiss MicroImaging, Jena, Germany). For measurements, five different sections from each sample were used, and three different cell and tissue measurements from each section were taken. To compare NGL and GLG, measurements adaxial surface cuticle thickness, adaxial and abaxial epidermal cell thickness, and the number of mesophyll cell layers were measured. In addition, parenchyma, abaxial and adaxial epidermal cell areas, in transverse sections of both NGL and GLG were measured. To compare GLG and CSG, the number of vascular bundles, the number of parenchyma cell layers in a transverse gall section, and parenchyma tissue thickness in gall walls were measured. Parenchymatous cell area and nymphal chamber area were also measured.

\section{Histochemical analysis}


For histochemical reactions, fresh samples of mature NGL and GLG $(n=5)$ were fixed in 2.5 $\%$ glutaraldehyde and $4.5 \%$ formaldehyde (4\% Karnovsky, $0.1 \mathrm{M}, \mathrm{pH}$ 7.2) (O’Brien and McCully 1981) for $24 \mathrm{~h}$, embedded in polyethylene glycol (PEG), and sectioned (20-40 $\mu \mathrm{m})$ using a rotary microtome (Leica 2035 Biocut) (Ferreira et al. 2014; Ferreira et al. 2017b). Each section was submitted to histochemical tests for starch (Lugol's reagent, Johansen 1940), reducing sugars (Fehling's reagent, Sass 1951), lipids (Sudan IV and Sudan red B, Brundett et al. 1991), and total proteins (mercuric bromophenol blue solution and acetic acid, Baker 1958). Treated sections were mounted on glass slides with $50 \%$ glycerin or water (Kraus and Arduin 1997), observed, and photographed with a light microscope (Leica ${ }^{\circledR}$ DM500) coupled with a digital camera (Leica ${ }^{\circledR}$ ICC50 HD), then compared with blank sections.

\section{Statistical analysis}

Student's T-test was used to compare NGL to GLG, and GLG to CSG for each independent variable. Data normality was verified with the Shapiro-Wilk test. Differences were significant at a probability of $5 \%(p<0.05)$. Statistical analysis was performed using InfoStat software (v.2013) (Rienzo et al. 2013).

\section{Results}

Phenology and morphological description of host organ and gall morphotype

Schinus polygama leaves are simple, elliptic, and usually glabrous with a conspicuous midrib (Fig. 1A, B). The first instar of C. mammifex (Hemiptera: Calophyidae) induces galls on the adaxial surface of the leaf lamina, generally near the midrib of young $S$. polygama leaves (Table 1). These galls are globoid, mostly located in the median and basal portions of the leaf, and less frequently in the apical region (Table 1). 
At the beginning of GD, galling insects form a globular projection on the abaxial surface of the leaf lamina (Fig. 1A, C), with white trichomes that close the aperture of the gall. GLG are randomly distributed; number and colour can vary on the same leaf lamina (Fig. 1D), regardless of insect developmental stage. The abaxial surface can be red, green, or intermediate color tones, while the adaxial surface generally remains green. Also, red and green galls are observed on the same leaf lamina (Fig. 1D). Senescent galls are dark brown and open to the abaxial surface (Fig. 1E) due to pressure exerted by adult terminalia.

Gall induction begins in mid-spring (October), and the first galls are observed in the growth and development phase at the end of spring in Southern Chile (November) (Fig. 2). From midsummer to late winter (January to August), only immature C. mammifex instars (I, II and III) are observed, indicating a diapause period in insect development. During the spring (November to December), galls open and the adults emerge, completing an annual life cycle. Schinus polygama is an evergreen plant, with little phenophase demarcation. A leaf-flushing peak occurs during spring, and leaves with senescent galls fall from the host plant in late spring (November) (Fig. 2).

\section{Anatomical features of non-galled leaves and leaf galls}

Mature S. polygama leaves are amphistomatic, with a smooth cuticle and uni-stratified epidermis (Fig. 3A, B). Leaf lamina are bifacial with two layers of palisade parenchyma facing the adaxial surface and a variable number of spongy parenchyma cell layers facing the abaxial surface (Fig. 3A). The spongy parenchyma cells are loosely organized, and both palisade and spongy parenchyma have idioblasts with crystal druses (Fig. 3B). Secretory ducts associate to vascular tissues, and are included in phloem parenchyma (Fig. 3A).

First instar nymph feeding activity induces a globoid gall with an ample chamber, sheltering a single gall inducer (Fig. 3C). Gall establishment occurs in the mesophyll, and a homogenous 
parenchyma is formed by hyperplasia and cell hypertrophy. Gall walls can be divided into an abaxial parenchymatous portion and an adaxial vascularized portion (Fig. 3D). The abaxial portion is formed of 7-10 non-vascularized cell layers with periclinal elongation (Fig. 3D). The abaxial projection terminates with the gall opening, from whence the adult emerges. The gall opening is covered by lignified multicellular uniseriate trichomes (Fig. 3C). The adaxial portion can be divided into three tissue compartments: outer (OC), median (MC), and inner compartments (IC) (Fig. 3D), derived from the adaxial, median, and abaxial layers of the leaf lamina ground meristem. The IC is formed of 4-5 non-vascularized cell layers with periclinal elongation and a uni-stratified epidermis forming the nymphal chamber outline (Fig. 3E). In the MC, neoformed vascular bundles occur, with well-developed vascular parenchyma (Fig. 3F). Vascular bundles are numerous and the phloem is oriented towards the nymphal chamber (Fig. 3G). A single layered epidermis with thick cuticle delimits the gall wall (Fig. $3 \mathrm{H}$ ).

During GD, galls increase in size due to continuous divisions of parenchyma cells. In the MP, a large number of vascular bundles are observed. The gall opening begins at the end of maturation, facilitating the adult's exit. The SP begins when the gall opens fully and the insect escapes (Fig. 3I). During this phase, the abaxial portion degrades rapidly, tissues are disorganized, and in the gall opening, suberization and trichome decay occur (Fig. 3J). Druses abound in the adaxial portion (Fig. 3F), and are numerous towards the abaxial portion throughout senescence (Fig. 3K).

Histochemical profiles of leaves and galls

Starch grains were detected throughout the chlorophyllous parenchyma (Fig. 4A, B) in nongalled leaves, but they were not detected in mature galls. Reducing sugars were detected in the mesophyll, bundle sheath cells, radial parenchyma (Fig. 4C), and in the outer and inner tissue 
compartments, and perivascular parenchyma of the galls (Fig. 4D, E). Lipid droplets were detected in the chlorophyllous parenchyma, vascular bundles, and secretory ducts in NGL, yet they were not as abundant in the epidermal cells (Fig. 4F). In GLG, lipids were detected both in outer and median compartments (Fig. 4G), as well as in phloem parenchyma cells (Fig. 4H). Proteins were observed in the spongy and vascular parenchyma of leaves (Fig. 4I). In GLG, proteins were mostly detected in median compartment cell walls (Fig. 4J).

\section{Quantitative comparison}

Every cytometric and histometric measurement was different between NGL and mature GLG, except for the abaxial epidermal cell area (Table 2). Adaxial cuticle thickness, adaxial and abaxial epidermal cell thickness, adaxial epidermal cell area, number of cortical cell layers, and parenchymatous cell area were all greater in mature galls than in NGL (Table 2). Abaxial epidermal cell area was similar in NLG and GLG (Table 2).

The two mature gall morphotypes differed in some parameters (Table 3). The number of cell layers and the thickness of gall cortex were significantly greater in CSG than in GLG (Table 3). Parenchymatous cell area was also greater in CSG when compared to GLG (Table 3). Stem galls had more vascular units per transverse median section than GLG vascular bundles (Table 3). Nymphal chamber area was not significantly different between gall morphotypes (Table 3).

\section{Discussion}

The phenological features of C. mammifex-induced galls follow the expected pattern for Mediterranean climatic conditions of southern Chile. Some anatomical and histochemical features follow peculiarities determined by gall-inducing calophyid feeding habits. Accordingly, some gall features are determined by developmental constraints imposed by S. polygama host organs. In stem galls, the increased vascular unit differentiation may be related to the 
physiological and anatomical potential of stems, with cambial and procambial meristematic regions.

Diagnostic features of Calophya mammifex galls

Schinus polygama is an evergreen species with available oviposition sites throughout the year (Guedes et al. 2018). Nevertheless, C. mammifex induces galls only during the spring, probably due to unfavourable environmental conditions during summer, autumn and winter in the Mediterranean climate of southern Chile. This climate has cold, wet winters and hot, dry summers (Giorgi and Lionello 2008), which can determine the diapause period and univoltine life cycle of $C$. mammifex, as previously described for C. rubra in the same climatic conditions (Guedes et al. 2018). Galling insect reproductive success seems to be determined by environmental conditions and host-plant characteristics (Fernandes and Price 1992; Yukawa and Akimoto 2006). Multivoltine life cycles seem to occur due to subtropical and tropical climate conditions for other psylloid galls on evergreen plants (Dias et al. 2013b; Lima 2008), and have been associated to the constant availability of resources (Carneiro and Isaias 2015). However, in seasonal climates such as the Mediterranean climate of southern Chile, inducers such as $C$. mammifex and C. rubra must adapt their life cycles to periods with favourable conditions (Guedes et al. 2018).

Immediately after the rainy season, temperatures increase in Mediterranean climates, which triggers a leaf-flushing peak. Such conditions seem to favour diapause breaking, adult $C$. mammifex emergence, and the induction of a new gall cycle on young leaves. For most systems, this leaf-flushing period corresponds to the preferential time for gall induction (Abrahamson et al. 1991; Gonçalves-Alvim and Fernandes 2001), since young leaves seem to be more responsive to galling insect stimuli (Rohfritsch and Anthony 1992), and could guarantee the quality and 
quantity of available resources for insects (Yukawa 2000; Yukawa and Akimoto 2006). In addition, the selection of oviposition site is important for gall development, as it can determine nutrient allocation (Price and Roininen 1993) and improve sink-strength generated by the gall (Larson and Whitham 1997). Calophya mammifex preferentially induce galls in the median portion of leaves, as other Psylloidea (Weis et al. 1988; Ferreira et al. 1990; Dias et al. 2013b) and Cecidomyiidae (Formiga et al. 2009).

\section{Morphogenetic constraints of host leaves on C. mammifex galls}

The decription of the leaf anatomy of S. polygama coincides with that of Dias et al. (2013a) for S. engleri (reported as $S$. polygamus), a closely related species from southern Brazil. Dorsiventral mesophyll with druses and the presence of secretory structures embedded in phloem parenchyma are common features among Schinus (Blanco 2004; Nascimento-Silva et al. 2011).

Regarding the dermal system, C. mammifex influence has been constrained to the cuticle of gall development sites, and trichome differentiation in gall apertures. The thick cuticle of globoid leaf galls (GLG) implies a greater investment in protection against water loss, since cuticle reflects solar rays and maintains leaf tissue temperatures (Fahn 1992), and conditions outside the gall are highly desiccating (Ramløv et al. 2000), particularly considering that spring and summer are very dry in Mediterranean climate regions (Acevedo et al. 1999). The re-differentiation of trichomes in gall aperture has also been associated with insect protection, against natural enemies as well as unfavourable environmental conditions (Guedes et al. 2016).

The histochemical profile of globoid leaf galls also reveals high constraints of host leaf metabolism, which is inferred by the similarity between the histochemical detection of the metabolites between host leaves and galls, except for the absence of starch in galls. Calophya mammifex-induced galls probably have a weak capacity to synthesize photoassimilates, and 
function primarily as sink of resource (Weis et al. 1988; Raman et al. 2006; Álvarez et al. 2009). The accumulation of reducing sugars, proteins, and lipids in gall phloem and vascular parenchyma indicates high metabolic activity and the re-differentiation of a nutritive-like tissue (Ferreira et al. 2017a). Lipids and proteins were also detected in gall outer tissue compartments (OC), indicating their function as common storage tissues (Ferreira et al. 2017a). The accumulation of primary metabolites and druses in galls indicates a redirection of non-galled host organ patterns (Schonrogge et al. 1998), and it has been reported for Psylloidea galls in Neotropical climates (Oliveira et al. 2006; Oliveira et al. 2010; Isaias et al. 2011; Carneiro et al. 2014a, b; Malenovský et al. 2015). In Mediterranean conditions, such accumulation is a product of the peculiar reduced gall metabolism throughout summer, autumn and winter.

Peculiarities of C. mamifex-induced galls vs. C. rubra-induced galls

Cell hypertrophy and tissue hyperplasia, as observed in C. mammifex-induced galls, are the most common cellular processes in gall development (Mani 1964). The larger number of cell layers and higher cells in stem galls induced by $C$. rubra than in leaf galls induced by $C$. mammifex may be explained by the activation of vascular procambium and cambium during stem gall development (Mani 1964; Guedes et al. 2018). The differential rates of hyperplasia and cell hypertrophy in distinct tissue compartments determine the distinct gall shapes (Isaias and Oliveira 2014).

The reorganization of plant vascular tissues during gall development (Oliveira et al. 2016) facilitates nutrient translocation and access to host-plant nutrients by the galling insects (Wool et al. 1999). Therefore, the neoformation of vascular bundles and a well-developed vascular parenchyma is expected for sap-feeding insects (Shorthouse and Rohfritsch 1992; Wool et al. 1999; Raman 2011), such as C. mammifex, which has two feeding sites, the phloem - its main 
food source - and the vascular parenchyma. The differentiation of new vascular tissues in GLG and CSG (Guedes et al. 2018) - mostly phloem - is directed to the nymphal chamber and grows like a mantle around the inner compartment in the adaxial portion. The orientation of the phloem portions toward the nymphal chamber is similar to the common orientation of vascular bundles in leaves (Álvarez et al. 2009; Ferreira et al. 2017a), and favours the feeding process, as the stylets of the inducing insect can suck phloem sap without crossing the xylem.

In woody perennials like $S$. polygama, the auxin produced by growing buds in spring stimulates procambium activation in a basipetal direction (Taiz and Zeiger 2006). This stimulus may explain the neoformation of vascular units by procambium activation in CSG, which is the most conspicuous difference between leaf and stem galls in $S$. polygama. This peculiarity is evidence that the host organ's morphogenetic potential determines gall anatomy.

Despite the quantitative differences in tissue layers and vascular tissues, there are numerous convergences between GLG and CSG. Many anatomical characteristics of the two gall morphotypes are likely conserved traits in Psylloidea, particularly in Calophyidae-induced galls (C. mammifex, C. rubra, and C. cf. duvauae), where three general features are convergent, and independent of host organs. First, the three morphotypes are open galls, with overlapping trichomes covering gall apertures; second, the nymphal chambers are large, even when hosting a single small inducing-insect; and third, Calophyidae-induced galls are highly parenchymatic and vascularized, with abundant development of phloem and vascular parenchyma.

Recently, gall complexity was evaluated based on the occurrence of one or several anatomical features such as cell hypertrophy, tissue hyperplasia, vascular bundle hypertrophy, cell re-differentiation, histochemical changes, and manipulation of meristematic activity (Ferreira et al. 2017a). Considering the anatomical and histochemical features, C. mammifex and C. rubra 
may be considered complex galls, contrary to the literature on Hemipteran galls (Rohfritsch 1992; Oliveira and Isaias 2010).

\section{Main conclusions}

Environmental conditions in the Mediterranean climate of southern Chile probably determine a univoltine life cycle and a diapause period for $C$. mammifex development on $S$. polygama, as well as the anatomical and histochemical features of its galls. For the first time, we detected energetic metabolites in a nutritive-like tissue and in a common storage tissue in galls in Mediterranean climate conditions, which may be related to the nutritional improvement of galls. Galls induced by C. mammifex and C. rubra have sufficient anatomical and histochemical peculiarities to be diagnosed as complex structures, whose distinction in vascular system differentiation implies structural constraints imposed by host plant organs.

\section{Acknowledgments}

This work was supported by the Comisión Nacional de Investigación Científica y Tecnológica (CONICYT, Chile) under Grant No 63140050 (National PhD/2014-fellowship) awarded to LMG; Vice-Rectory of Research and Development at the Universidad de Concepción, under Grant 215.142.034-1.0IN, Projects UCO1795 and REDI170025 funded by CONICYT Chile, Fundação de Amparo à Pesquisa do Estado de Minas Gerais (FAPEMIG, Brazil), Conselho Nacional de Desenvolvimento Científico e Tecnológico (CNPq, Brazil), and Coordenação de Aperfeiçoamento de Pessoal de Nível Superior (CAPES, Brazil). The authors are grateful to PD Dr. Daniel Burckhardt (Naturhistorisches Museum Basel, Switzerland) for his contribution to insect identification, Mr. Wagner A. Rocha, Miss Daniele R. Alvarenga and MSc Nina de Castro for their contribution to the anatomical and histochemical techniques.

\section{References}


Abrahamson, W.G., McCrea, K.D., Whitwell, A.J., and Vernieri, L.A. 1991. The role of phenolics in goldenrod ball gall resistance and formation. Biochem. Syst. Ecol. 19: 615-622. doi:10.1016/0305-1978(91)90077-D.

Abrahamson, W.G., and Weis, A.E. 1997. Evolutionary ecology across three trophic levels: goldenrods, gallmakers, and natural enemies. Princeton University Press.

Acevedo, E.H., Silva, P.C., Silva, H.R., and Solar, B.R. 1999. Wheat production in Mediterranean environments. In Ecology and physiology of yield determination. Edited by E.H. Satorre and G.A. Slafer. Food Products Press, NY. pp. 295-323.

Álvarez, R., Encina, A., and Pérez-Hidalgo, N. 2009. Histological aspects of three Pistacia terebinthus galls induced by three different aphids: Paracletus cimiciformis, Forda marginata and Forda formicaria. Plant Sci. 176: 303-314. doi:10.1016/j.plantsci.2008.11.006.

Armesto, J.J., Arroyo M.T.K., and Hinojosa, L.F. 2007. The Mediterranean environment of central Chile. In The physical geography os South America. Edited by T.T. Veblen, K.R. Young and A.R. Orme. Oxford University Press, UK. pp. 184-199.

Baker, J.R. 1958. Note on the use of bromophenol blue for the histochemical recognition of protein. Quart. J. Microsc. Sci. 99: 459-460.

Blanco, C.A. 2004. La hoja: morfología externa y anatomía. Universidad Nacional del Litoral.

Brundett, M.C., Kendrick, B., and Peterson, C.A. 1991. Efficient lipid staining in plant material with Sudan Red 7B or fluoral yellow 088 in polyethylene glycol-glycerol. Biotech. Histochem. 66: 111-116. doi:10.3109/10520299109110562 
Bukatsch, F. 1972. Bermerkungen zur doppelfärbung astrablau-safranin. Mikrokosmos, 61: 255.

Burckhardt, D., and Basset, Y. 2000. The jumping plant-lice (Hemiptera, Psylloidea) associated with Schinus (Anacardiaceae): systematics, biogeography and host plant relationships. J. Nat. Hist. 34: 57-155. doi:10.1080/002229300299688.

Carneiro, R.G.S., Oliveira, D.C., and Isaias, R.M.S. 2014a. Developmental anatomy and immunocytochemistry reveal the neo-ontogenesis of the leaf tissues of Psidium myrtoides (Myrtaceae) towards the globoid galls of Nothotrioza myrtoides (Triozidae). Plant Cell Rep. 33: 2093-2106. doi:10.1007/s00299-014-1683-7.

Carneiro, R.G.S., Castro, A.C., and Isaias, R.S.M. 2014b. Unique histochemical gradients in a photosynthesis-deficient plant gall. S. Afr. J. Bot. 92: 97-104. doi:10.1016/j.sajb.2014.02.011.

Carneiro, R.G.S., and Isaias, R.S.M. 2015. Gradients of metabolite accumulation and redifferentiation of nutritive cells associated with vascular tissues in galls induced by sucking insects. AoB Plants, 24(7): 1-16. doi:10.1093/aobpla/plv086.

Dias, G.G., Ferreira, B.G., Moreira, G.R.P., and Isaias, R.M.S. 2013a. Developmental pathway from leaves to galls induced by a sap-feeding insect on Schinus polygamus (Cav.) Cabrera (Anacardiaceae). An. Acad. Bras. Ciências, 85: 187-200. doi:10.1590/S000137652013000100010.

Dias, G.G., Moreira, G.R.P., Ferreira, B.G., and Isaias, R.M.S. 2013b. Why do the galls induced by Calophya duvauae Scott on Schinus polygamus (Cav.) Cabrera (Anacardiaceae) change color? Biochem. Syst. Ecol. 48: 111-122. doi:10.1016/j.bse.2012.12.013.

Fahn, A., and Cutler, D.F. 1992. Xerophytes. Gebrüder Borntraeger, Stuttgart. 
Fernandes, G.W., and Price, P.W. 1992. The adaptive significance of insect gall distribution: survivorship of species in xeric and mesic habitats. Oecologia, 90: 14-20. doi:10.1007/BF00317803.

Ferreira, B.G., Teixeira, C.T., and Isaias, R.S.M. 2014. Efficiency of the polyethylene-glycol (PEG) embedding medium for plant histochemistry. J. Histochem. Cytochem. 62(8): 577583. doi:10.1369/0022155414538265.

Ferreira, B.G., Falcioni, R., Guedes, L.M., Avritzer, S.C., Antunes, W.C., Souza, L.A., and Isaias, R.S.M. 2017a. Preventing false negatives for histochemical detection of phenolics and lignins in PEG-embedded plant tissues. J. Histochem. Cytochem. 65(2): 1-12. doi:10.1369/0022155416677035.

Ferreira, B.G., Álvarez, R., Avritzer, S., and Isaias, R.S.M. 2017b. Revisiting the histological patterns of storage tissues: beyond the limits of gall-inducing taxa. Botany, 95(2): 173-184. doi:10.1139/cjb-2016-0189.

Ferreira, S.A., Fernandes, G.W., and Carvalho, L.G. 1990. Biologia e história natural de Euphaleurus ostreoides (Homoptera: Psillidae) cecidógeno de Lonchocarpus guillerminianus (Leguminosae). Rev. Bras. Biol. 50(2): 417-423.

Formiga, A.T., Gonçalves, S.J.M.S., Soares, G.L.G., and Isaias, R.M.S. 2009. Relações entre o teor de fenóis totais e o ciclo das galhas de Cecidomyiida e em Aspidosperma spruceanum Müll. Arg. (Apocynaceae). Acta Bot. Bras. 23(1): 93-99. doi:10.1590/S010233062009000100012.

Formiga, A.T., Silveira, F.A.O., Fernandes, G.W., and Isaias, R.M.S. 2015. Phenotypic plasticity and similarity among gall morphotypes on a superhost, Baccharis reticularia (Asteraceae). Plant Biol. 17(2): 512-521. doi:10.1111/plb.12232. 
Giorgi, F., and Lionello, P. 2008. Climate change projections for the Mediterranean region. Glob. Planet Change, 63: 90-104. doi:10.1016/j.gloplacha.2007.09.005.

Gonçalves-Alvim, S.J., and Fernandes, G.W. 2001. Biodiversity of galling insects: historical, community and habitat effects in four neotropical savannas. Biodivers. Conserv. 10(1): 7998. doi:10.1023/A:1016602213305.

Guedes, L.M., Aguilera, N., Becerra, J., Hernández, V., and Isaias, R.M.S. 2016. Leaf and stem galls of Schinus polygamus (Cav.) Cabr (Anacardiaceae): Anatomical and chemical implications. Biochem. Syst. Ecol. 69: 266-273. doi:10.1016/j.bse.2016.10.012.

Guedes, L.M., Aguilera, N., Ferreira, B.G., Becerra, J., Hernández, V., and Isaias, R.M.S. 2018. Anatomical and phenological implications between Schinus polygama (Cav.) (Cabrera) (Anacardiaceae) and the galling insect Calophya rubra (Blanchard) (Hemiptera: Psylloidea). Plant Biol. 20: 507-515. doi:10.1111/plb.12696.

Isaias, R.M.S., Oliveira, D.C., and Carneiro, R.G.S. 2011. Role of Euphalerus ostreoides (Hemiptera: Psylloidea) in manipulating leaflet ontogenesis of Lonchocarpus muehlbergianus (Fabaceae). Botany, 89(9): 581-592. doi:10.1139/b11-048.

Isaias, R.M.S., and Oliveira, D.C. 2014. Gall phenotypes - product of plant cells defensive responses to the inducers attack. In Neotropical insect galls. Edited by G.W. Fernandes and J.C. Santos. Springer Netherlands, Dordrecht. pp. 273-290.

Isaias, R.M.S., Carneiro, R.G.S., Santos, J.C., and Oliveira, D.C. 2014. Gall morphotypes in the neotropics and the need to standardize them. In Neotropical insect galls. Edited by G.W. Fernandes and J.C. Santos. Springer Netherlands, Dordrecht. pp. 57-67. 
Johansen, D.A. 1940. Plant microtechnique. McGraw-Hill Book, New York.

Karnovsky, M.J. 1965. A formaldehyde-glutaraldehyde fixative of high osmolarity for use in electron microscopy. J. Cell Biol. 27: 137-138.

Kraus, J.E., and Arduin, M. 1997. Manual Básico de Métodos em Morfologia Vegetal. Editora da Universidade Federal Rural do Rio de Janeiro, Seropédica, Brazil.

Larson, K.C., and Whitham, T.G. 1991. Manipulation of food resources by a gall-forming aphid: the physiology of sink-source interactions. Oecologia, 88: 15-21. doi:10.1007/BF00328398.

Lima, F.S. 2008. Respostas estruturais e fisiológicas de Richeria grandis Vahl. (Phyllanthaceae) ao estabelecimento do Psyllidae galhador. PhD. Thesis, Department of Botany, Universidade Federal de Minas Gerais, Minas Gerais.

Malenovský, I., Burckhardt, D., Queiroz, D.L., Isaias, R.S.M., and Oliveira, D.C. 2015 Descriptions of two new Pseudophacopteron species (Hemiptera: Psylloidea: Phacopteronidae) inducing galls on Aspidosperma (Apocynaceae) in Brazil. Acta Etomol. Mus. Nat. Pragae, 55(2): 513-538. doi:10.1590/S0102-33062010000300016.

Mani, M.S. 1964. Ecology of plant galls. Dr. W. Junk Publishers, The Hague.

Meyer, J. 1987. Cécidogenêse comparée de quelques galles d'arthropodes et évolution cytologique des tissus nouriciers. Unpublished thesis, University of Strasbourg.

Moura, M.Z.D., Soares, G.L.G., and Isaias, R.M.S. 2008. Speciesspecific changes in tissue morphogenesis induced by two arthropod leaf gallers in Lantana camara L. (Verbenaceae). Aust. J. Bot. 56: 153-160. doi:10.1071/BT07131.

Nascimento-Silva, O., Leite, D.S., Bernardes, L.A., and Paiva, J.G.A. 2011. Morphology, anatomy and histochemistry of the leaves of Myracrodruon urundeuva Allemão (Anacardiaceae). BLACPMA, 10(1): 56-66. 
O'Brien, T.P., and Mccully, M.E. 1981. The study of plant structure principles and selected methods. Termarcarphi Pty, Melbourne.

Oliveira, D.C., Christiano, J.C.S., Soares, G.L.G., and Isaias, R.M.S. 2006. Reações de defesas químicas e estruturais de Lonchocarpus muehlbergianus Hassl. (Fabaceae) à ação do galhador Euphalerus ostreoides Crawf. (Hemiptera: Psyllidae). Braz. J. Bot. 29: 657-667. doi:10.1590/S0100-84042006000400015.

Oliveira, D.C., and Isaias, R.M.S. 2010. Redifferentiation of leaflet tissues during midrib gall development in Copaifera langsdorffii (Fabaceae). S. Afr. J. Bot. 76: 239-248. doi:10.1016/j.sajb.2009.10.011.

Oliveira, D.C., Isaias, R.M.S., Fernandes, G.W., Ferreira, B.G., Carneiro, R.G.S., and Fuzaro, L. 2016. Manipulation of host plant cells and tissues by gall-inducing insects and adaptive strategies used by different feeding guilds. J. Insect Physiol. 84: 103-113. doi:10.1016/j.jinsphys.2015.11.012.

Paiva, J.G.A., Fank-de-Carvalho, S.M., Magalhães, M.P., and Graciano-Ribeiro, D. 2006. Verniz vitral incolor $500 \circledR$ : uma alternativa de meio de montagem economicamente viável. Acta Bot. Bras. 20: 257-264. doi:10.1590/S0102-33062006000200002.

Price, P.W., and Roininen, H. 1993. Adaptive radiation in gall induction. In Sawfly life history adaptations to woody plants. Edited by M. Wagner and K.F. Raffa. Academic Press, NY. pp. $229-257$.

Raman, A., Muniappan, R.N., Silva-Krott, I.U., and Reddy, G.V.P. 2006. Induced-defense responses in the leaves of Chromolaena odorata consequent to infestation by Pareuchaetes pseudoinsulata (Lepidoptera: Arctiidae). J. Plant Dis. Prot. 113(5): 234-239. doi:10.1007/BF03356187. 
Raman, A. 2011. Morphogenesis of insect-induced plant galls: facts and questions. Flora, 206(6): 517-533. doi:10.1016/j.flora.2010.08.004.

Ramløv, H., Richard, E., and Lee, J.R. 2000. Extreme resistance to desiccation in overwintering larvae of the gall fly Eurosta solidaginis (Diptera, Tephritidae). J. Exp. Biol. 20: 783-789.

Rienzo, J.A., Casanoves, F., Balzarini, M.G., Gonzalez, L., Tablada, M., and Robledo, C.W. 2013. InfoStat versión 2013. Grupo InfoStat, FCA, Universidad Nacional de Córdoba, Argentina.

Rohfritsch, O., and Anthony, M. 1992. Strategies on gall induction by two groups of homopterans. In Biology of insect-induced galls. Edited by J.D. Shorthouse and O. Rohfristsch. Oxford University Press, New York, pp. 102-123.

Rohfritsch, O. 1992. Patterns in gall development. In Biology of insect-induced galls. Edited by J.D. Shorthouse and O. Rohfritsch. Oxford University, Oxford. pp. 60-86.

Sass, J.E. 1951. Botanical microtechnique. $2^{\mathrm{a}}$ edn. Iowa State College Press, Iowa.

Schonrogge, K., Harper, L.J., Brooks, S.E., Shorthouse, J.D., and Lichtenstein, C.P. 1998. Reprogramming plant development: two approaches to study the molecular mechanism of gall formation. In The biology of gall-inducing arthropods. Edited by G. Csoka, W.J. Mattson, G.N. Stone and P.W. Price. General Technical Report NC 199. USDA Forest Service, Minnesota. pp 153-160.

Shorthouse, J.D., and Rohfritsch, O. 1992. Biology of insect-induced galls. Oxford University Press, New York.

Taiz, L., and Zeiger, E. 2006. Fisiología vegetal. Universitat Jaume I, Castellón de la Plana. Weis, A.E., Walton, R., and Crego, L.R. 1988. Reactive plant tissue sites and the population biology of gall makers. Annu. Rev. Entomol. 33: 467-486. doi:10.1146. 
Wool, D., Aloni, R., Ben-Zvi, O., and Wollberg, M. 1999. A galling aphid furnishes its home with a built-in pipeline to the host food supply. Entomol. Exp. Appl. 91: 183-186. doi:10.1046/j.1570-7458.1999.00482.x.

Yukawa, J. 2000. Synchronization of gallers with host plant phenology. Popul. Ecol. 42: $105-$ 113. doi:10.1007/PL00011989.

Yukawa, J., and Akimoto, K. 2006. Influence of synchronization between adult emergence and host plant phenology on the population density of Pseudasphondylia neolitsea (Diptera: Cecidomyiidae) inducing leaf galls on Neolitsea sericea (Lauraceae). Popul. Ecol. 48: 1321. doi:10.1007/s10144-005-0233-0. 
Legends

Table 1. Calophya mammifex (Hemiptera: Calophyidae) gall position on Schinus polygama (Anacardiaceae) leaves

Table 2. Cytometry and histometry of non-galled leaves (NGL) and mature globoid leaf galls (GLG) induced by Calophya mammifex (Hemiptera: Calophyidae) on Schinus polygama (Anacardiaceae)

Table 3. Cyto-histometric comparison between globoid leaf galls (GLG) and conical stem galls (CSG) on Schinus polygama (Anacardiaceae)

Figure captions

Figure 1. Non-galled leaves and Calophya mammifex leaf galls on Schinus polygama. A) Branch with young leaves and galls at the beginning of growth and development phase (white arrows). B) Mature non-galled leaf with conspicuous midrib. C) Abaxial surface of leaf lamina with abundant galls at the beginning of growth and development stage closed by white trichomes (boxed areas). D) Leaf lamina with abundant galls of different colors in final stage of growth and development. E) Leaf lamina with open senescent galls. Bars: $1 \mathrm{~cm}$.

Figure 2. Univoltine life cycle of Calophya mammifex on Schinus polygama leaves. Gall induction occurs during the leaf-flushing peak (October to November). Growth and development stage ranges from November until mid-September, when galls enter the maturation stage, which lasts until mid-November. The senescence stage goes from October until November, when leaves with senescent galls fall from the host plant.

Figure 3. Leaf and gall anatomy. A-B) Mature Schinus polygama leaf. A) Bifacial leaf lamina with palisade parenchyma facing the adaxial surface and spongy parenchyma facing the abaxial 
surface. B) Adaxial epidermal surface with druses (arrowheads). C-J) Leaf gall induced by Calophya mammifex. C) Mature gall with large nymphal chamber (arrow indicates gall opening). D) Gall walls divided into an abaxial (dotted red box) portion and an adaxial portion (dotted black box), divided into three compartments. E) Inner compartment with multi-layered cells of periclinal elongation and uniseriate abaxial epidermis limiting the nymphal chamber. F) Welldeveloped vascular parenchyma in the median compartment with abundant druses (asterisks). G) A vascular bundle in the median compartment with phloem oriented toward the nymphal chamber (arrow). H) Outer compartment delimited by uniseriate epidermis with thick cuticle. IK) Senescent gall (double arrow indicates separation of gall opening), detail of red rectangle shows in: I) degraded and suberized tissues of abaxial portion, and J) abundant druses in abaxial portion of the senescent gall. Abbreviations: AbEp: abaxial epidermis, AdEp: adaxial epidermis, AbP: abaxial portion, AdP: adaxial portion, $\mathrm{Cu}$ : cuticle, Ep: epidermis, GC: gall cortex, IC: inner compartment, LL: leaf lamina, MC: median compartment, $\mathrm{NC}$ : nymphal chamber, OC: outer compartment, Ph: phloem, PP: palisade parenchyma, SD: secretory ducts, SP: spongy parenchyma, VB: vascular bundle, VP: vascular parenchyma, Xy: xylem. Druses (*). Bars: 50 $\mu \mathrm{m}(\mathrm{A}, \mathrm{B}, \mathrm{E}-\mathrm{K}), 500 \mu \mathrm{m}(\mathrm{C})$.

Figure 4. Histolocalization of metabolites in Schinus polygama leaves and Calophya mammifex galls. A-B) Reaction of Lugol's reagent to starch in leaf tissues, A) around vascular bundle, B) in chlorophyllous parenchyma (arrowheads). C-E) Reactions of Felhing's reagent to reducing sugars, C) in leaf chlorophyllous parenchyma, endoderm, phloem and secretory ducts, and D) in inner compartment, surrounding the vascular bundles of the gall. E) Detail of vascular bundle in the gall, with reducing sugars in phloem, endoderm and cortical cells. F) Reaction of Sudan IV to lipids in leaf chlorophyllous parenchyma (arrowheads). G-H) Reaction of Sudan red B to lipids in 
the gall, G) in outer and inner compartments, and $\mathrm{H}$ ) in neoformed vascular bundles (arrowheads). I-J) Reaction to bromophenol blue revealing proteins, I) in spongy leaf parenchyma (arrow), J) in gall median compartment (arrow). Abbreviations: MC: median compartment, NCh: nymphal chamber, Ph: phloem, PP: palisade parenchyma, SD: secretory ducts, SP: spongy parenchyma, VB: vascular bundle, Xy: xylem. Druses (*). Bars: $50 \mu \mathrm{m}(\mathrm{B}, \mathrm{E}-$ H), $200 \mu \mathrm{m}(\mathrm{A}, \mathrm{C}, \mathrm{D}, \mathrm{I}, \mathrm{J})$. 
Table 1. Calophya mammifex (Hemiptera: Calophyidae) gall position on Schinus polygama (Anacardiaceae) leaves

\begin{tabular}{lcc}
\hline $\begin{array}{l}\text { Position of } \\
\text { galls on the } \\
\text { leaf lamina }\end{array}$ & $\begin{array}{c}\text { Total } \\
\text { galls }\end{array}$ & $\mathbf{( \% )}$ \\
\hline Apex & 66 & 14.9 \\
Mid portion & 211 & 47.5 \\
Base & 167 & 37.6 \\
& & \\
Leaf margin & 100 & 22.5 \\
Leaf inner & 344 & 77.5 \\
& & \\
Total Galls & $\mathbf{4 4 4}$ & - \\
\hline
\end{tabular}


Table 2. Cytometry and histometry of non-galled leaves (NGL) and mature globoid leaf galls (GLG) induced by Calophya mammifex (Hemiptera: Calophyidae) on Schinus polygama (Anacardiaceae)

\begin{tabular}{lccc}
\hline Parameter & NGL & GLG & P-value \\
\hline Adaxial cuticule thickness $(\mu \mathrm{m})$ & $6.1 \pm 1.3 \mathrm{~b}$ & $8.9 \pm 1.8 \mathrm{a}$ & 0.0001 \\
Adaxial epidermis thickness $(\mu \mathrm{m})$ & $16.3 \pm 2.2 \mathrm{~b}$ & $27.0 \pm 6.8 \mathrm{a}$ & 0.0001 \\
Adaxial epidermal cell area $\left(\mu \mathrm{m}^{2}\right)$ & $360.2 \pm 86.5 \mathrm{~b}$ & $498.4 \pm 153.9 \mathrm{a}$ & 0.0003 \\
Parenchyma cell layers $(n)$ & $9.3 \pm 1.0 \mathrm{~b}$ & $14.9 \pm 2.8 \mathrm{a}$ & 0.0001 \\
Parenchymatic cell area $\left(\mu \mathrm{m}^{2}\right)$ & $426.5 \pm 145.9 \mathrm{~b}$ & $535.5 \pm 133.9 \mathrm{a}$ & 0.0194 \\
Abaxial epidermis thickness $(\mu \mathrm{m})$ & $13.7 \pm 2.3 \mathrm{~b}$ & $16.5 \pm 2.9 \mathrm{a}$ & 0.0014 \\
Abaxial epidermal cell area $\left(\mu \mathrm{m}^{2}\right)$ & $338.6 \pm 98.9 \mathrm{a}$ & $333.6 \pm 97.0 \mathrm{a}$ & 0.8582 \\
\hline
\end{tabular}

Data represent mean \pm standard deviation. Different letters mean significant differences $(p<0.05)$. 
Table 3. Cyto-histometric comparison between globoid leaf galls (GLG) and conical stem galls (CSG) on Schinus polygama (Anacardiaceae)

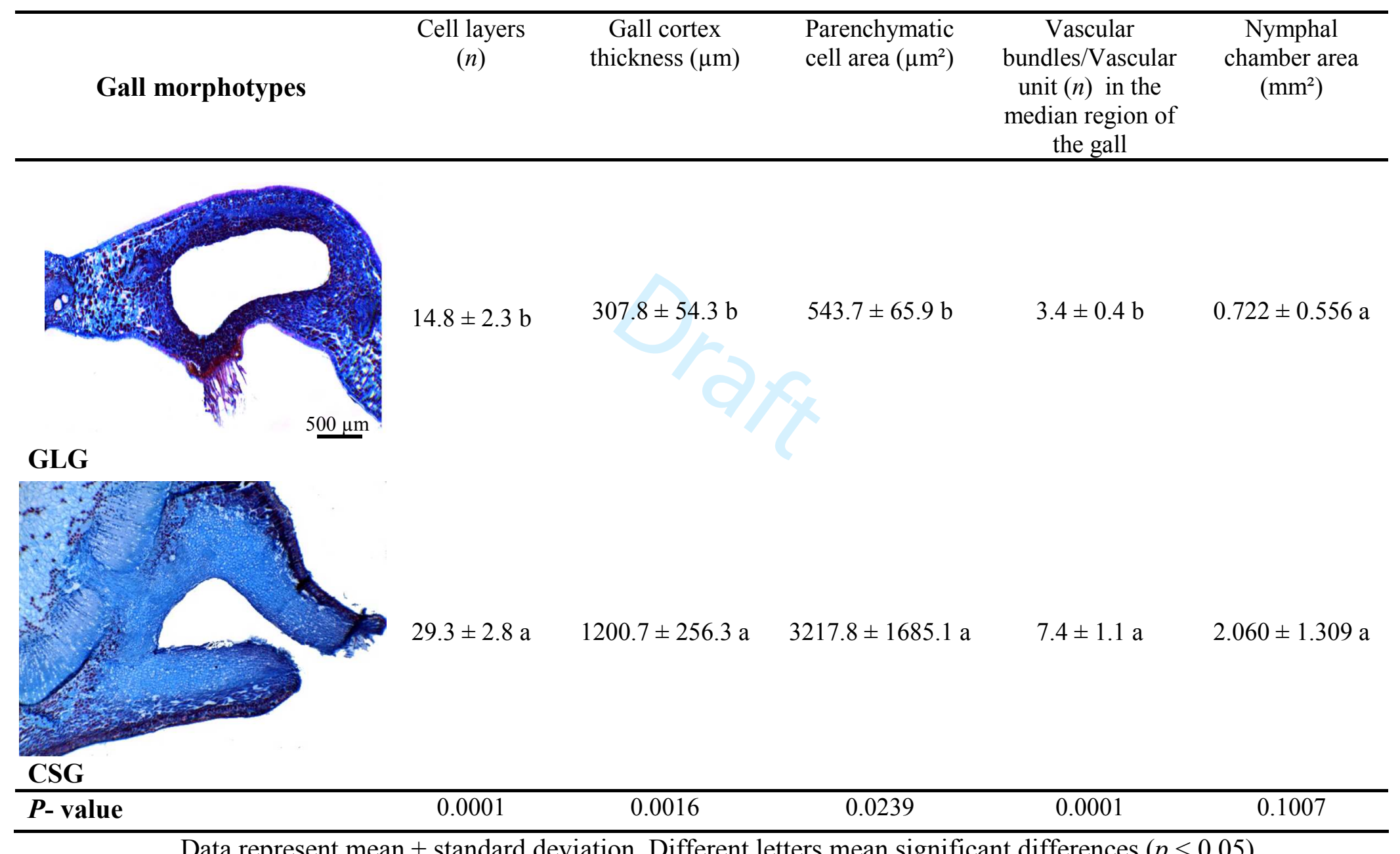

Data represent mean \pm standard deviation. Different letters mean significant differences $(p<0.05)$. 

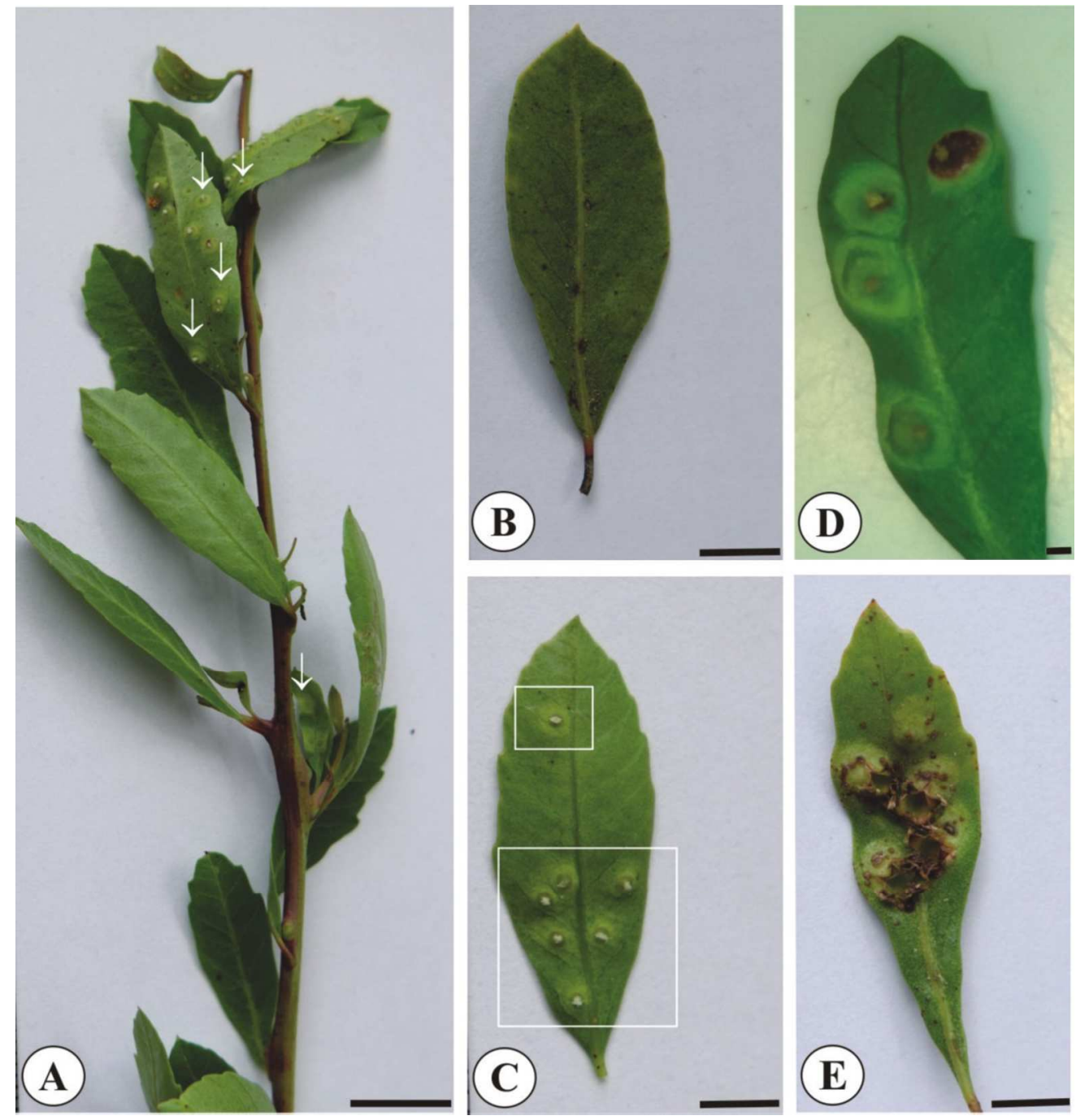

Non-galled leaves and Calophya mammifex leaf galls on Schinus polygama. $110 \times 116 \mathrm{~mm}(300 \times 300 \mathrm{DPI})$ 
Leaf flushing peak

Vegetative growth

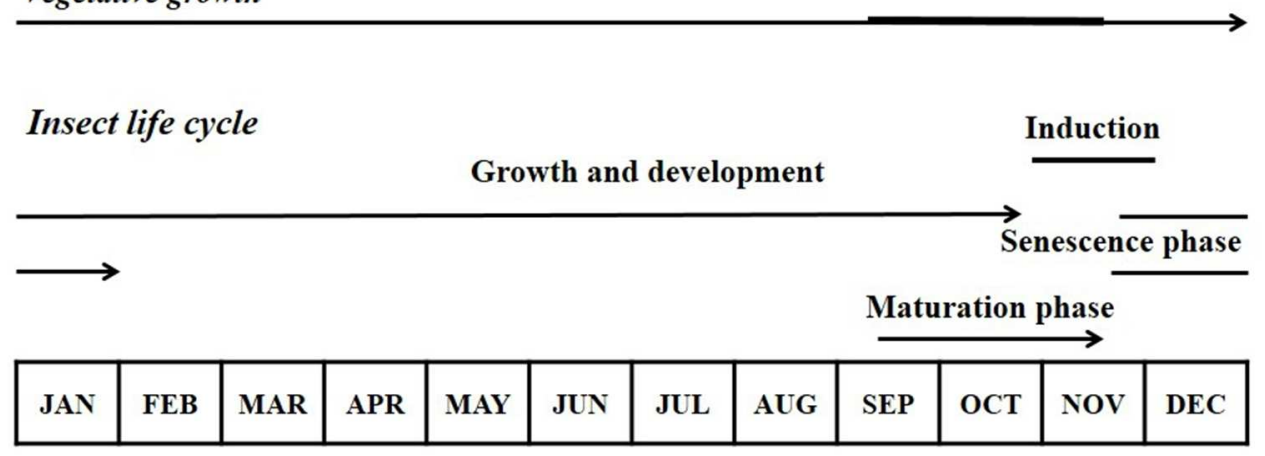

Figure 2. Univoltine life cycle of Calophya mammifex on leaves of Schinus polygama. Gall induction occurs during the flushing peak of leaves (October to November).

$254 \times 190 \mathrm{~mm}(96 \times 96 \mathrm{DPI})$ 


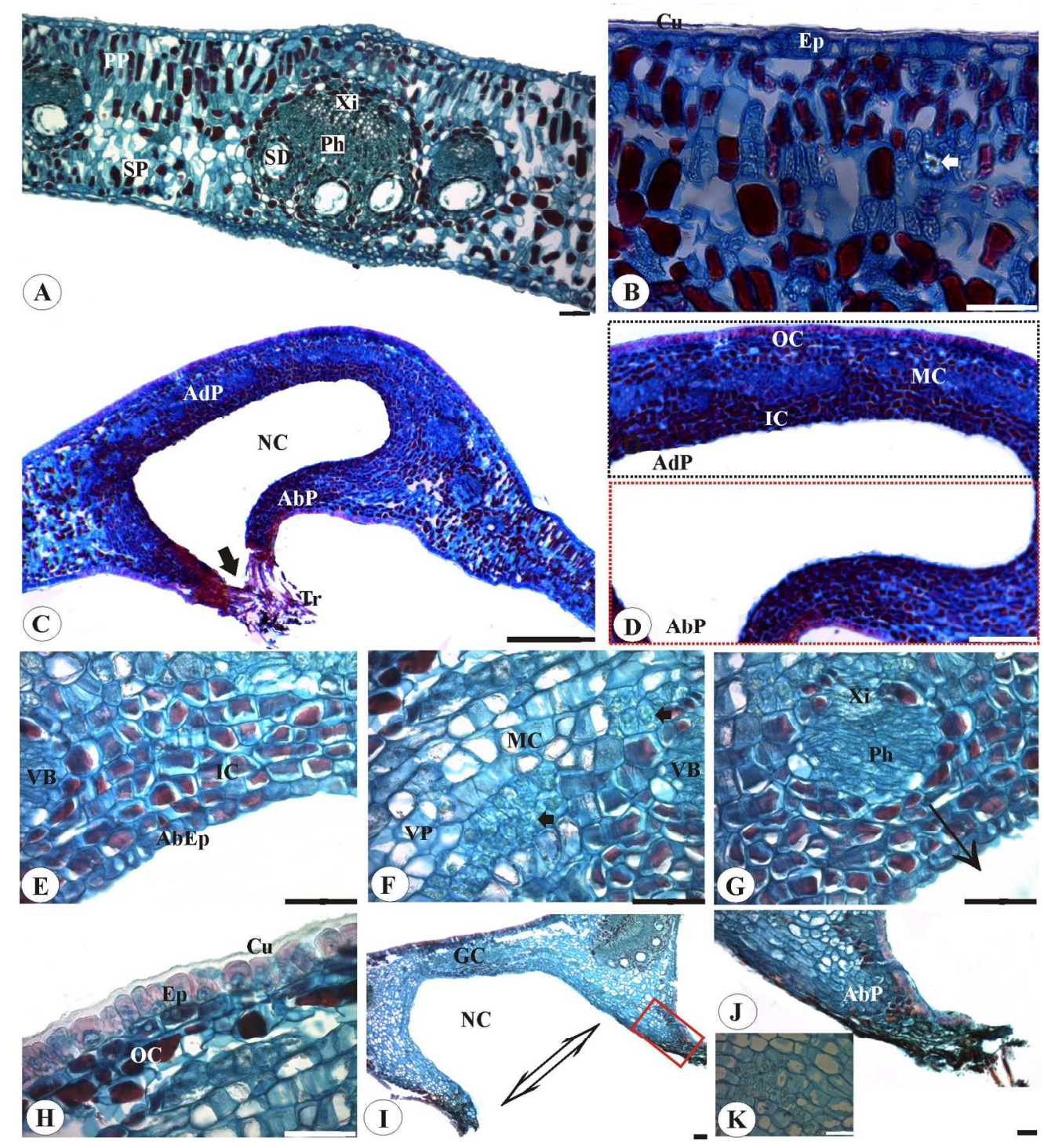

Figure 3. Leaf and gall anatomy

$166 \times 185 \mathrm{~mm}(300 \times 300$ DPI $)$ 

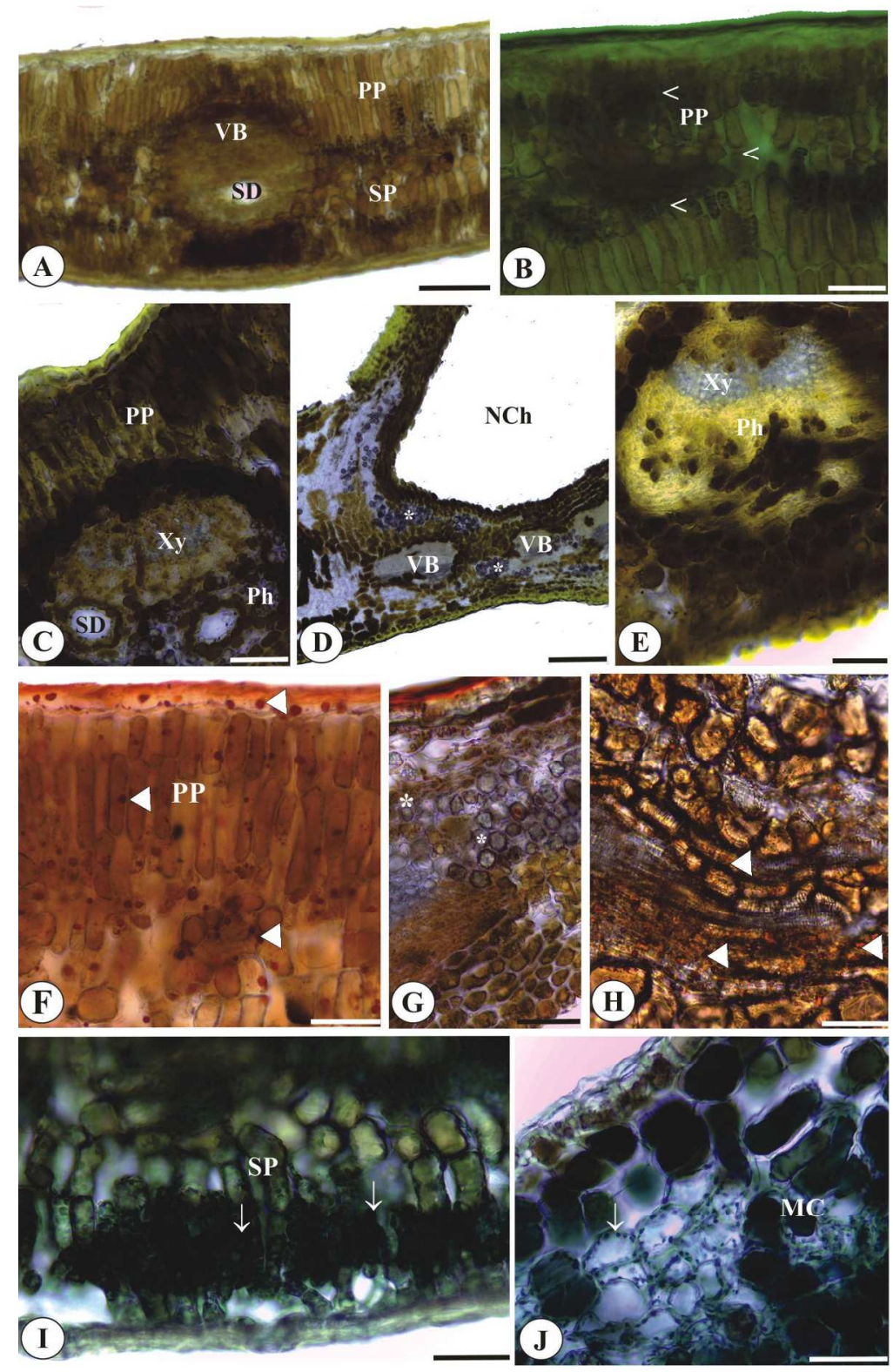

Figure 4. Histolocalization of metabolites in Schinus polygama leaves and Calophya mammifex galls. $130 \times 204 \mathrm{~mm}(300 \times 300$ DPI $)$ 